\title{
The Cupola: an additional layer of protection for providers working in the oropharyngeal region
}

\author{
Alessandro Villa ${ }^{1 *}$ (i) and Marlene Grenon ${ }^{2,3}$
}

\begin{abstract}
Objectives: To reduce the spread of the infection, especially during aerosol generating procedures, we invented "The Cupola", a shield that creates a mechanical barrier around the patient's head and body. With this pilot study we aimed to assess the effectiveness of an additional layer of protection (The Cupola) developed for providers working in the oropharyngeal region.

Results: The mean number of $0.3 \mu \mathrm{m}$ particles with no Cupola was 3777 (SD: \pm 556 ), with The Cupola was 2068 (SD: \pm 1468$)$ and with the Cupola and Drape was 2031 (SD: \pm 1108$)(p<0.015)$. The mean number of $0.5 \mu m$ airborne particles with no Cupola was 65 (SD: \pm 7 ), with The Cupola was 29 (SD: \pm 28 ) and with the Cupola and Drape was 28 $(S D: \pm 23)(p<0.05)$. Results showed a significant reduction of aerosols generated during simulated dental procedures when the Cupola was used. The Cupola offers an extra layer of protection in addition to the recommended personal protective equipment.
\end{abstract}

Keywords: COVID-19, Aerosol, Shield

\section{Introduction}

Even though most countries have begun to allow the delivery of dental and medical services, providing safe oral healthcare routinely remains challenging due to the high transmissibility of the Severe acute respiratory syndrome coronavirus 2 (SARS-CoV-2 virus; coronavirus) and how easily it may be dispersed during aerosol-generating procedures [1]. SARS-CoV-2 is present in salivary and nasopharyngeal secretions of infected patients, and spreads through respiratory droplets (droplet nuclei less $<5 \mu \mathrm{m}$ in size) as well as small viral particles that can linger in the air $[2,3]$.

Global Coronavirus disease (or COVID-19) cases have surpassed 115 millions [4]. The COVID-19 pandemic is

\footnotetext{
*Correspondence: alessandro.villa@ucsf.edu

${ }^{1}$ Department of Orofacial Sciences, University of California San Francisco,

513 Parnassus Ave, Suite 512A, San Francisco, CA 94143, USA

Full list of author information is available at the end of the article
}

placing health care professionals performing aerosolgenerating procedures in the oropharyngeal region at risk for becoming infected and subsequently, become vectors of infection [5]. As such, patients, and especially vulnerable individuals for COVID-19 may hold off from obtaining dental care in view of the perceived risk of such visits and procedures [6]. The Health Policy Institute of the American Dental Association showed a possible 38\% decline in dental care spending in the U.S. in 2020 and $20 \%$ in 2021. In October, 2020 more than a half of dental practices were open with a lower patient volume (55.2\%) than usual [7].

Poor access to dental care can lead to untreated dental decay or other oral health infections, leaving people with no viable options other than visiting hospital emergency rooms, where treatment is costly and disrupts more urgent care needs, particularly in a time of crisis such as the current COVID-19 pandemic [8]. Additionally, missed routine dental visits represent failed 
opportunities to provide preventive oral health care and to identify oral manifestations of systemic diseases [9].

To reduce the spread of the infection, especially during aerosol generating procedures, we invented "The Cupola", a shield that creates a mechanical barrier around the patient's head and body, and allows health providers to perform their work unhindered (Fig. 1a) [10]. "The Cupola" includes a face shield on a cart (or anchored to the dental chair) and a disposable waterproof surgical utility drape with tape around the shield to cover the patient head and body (as an additional option). The shield can be reused after disinfection with an Environmental Protection Agency (EPA)-registered, hospital-grade disinfectant.

We hypothesized that the use of The Cupola during aerosol generating procedures in the oropharyngeal region decreases the spread of droplets and aerosols in dental offices, which could lead to safer dental practices. This has potential implications to decrease the spread of disease among dentists, maxillofacial surgeons, otolaryngologists and their patients. The aim of this pilot study is to assess the efficacy of The Cupola in decreasing the spread of droplets and aerosols during simulated aerosol generating dental procedures.

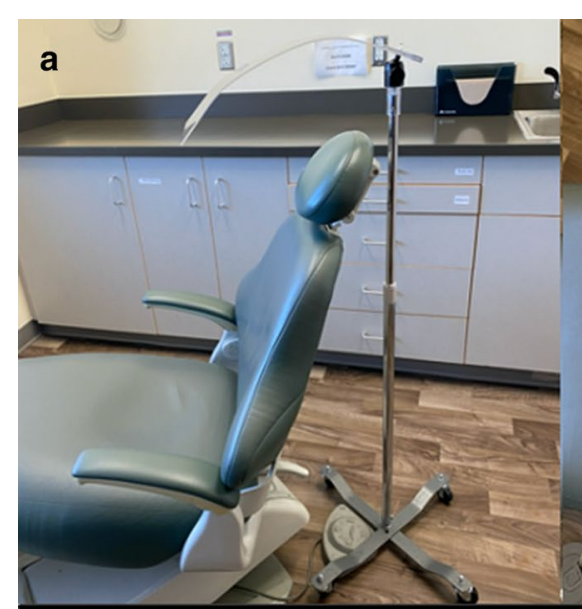

b
Without The Cupola

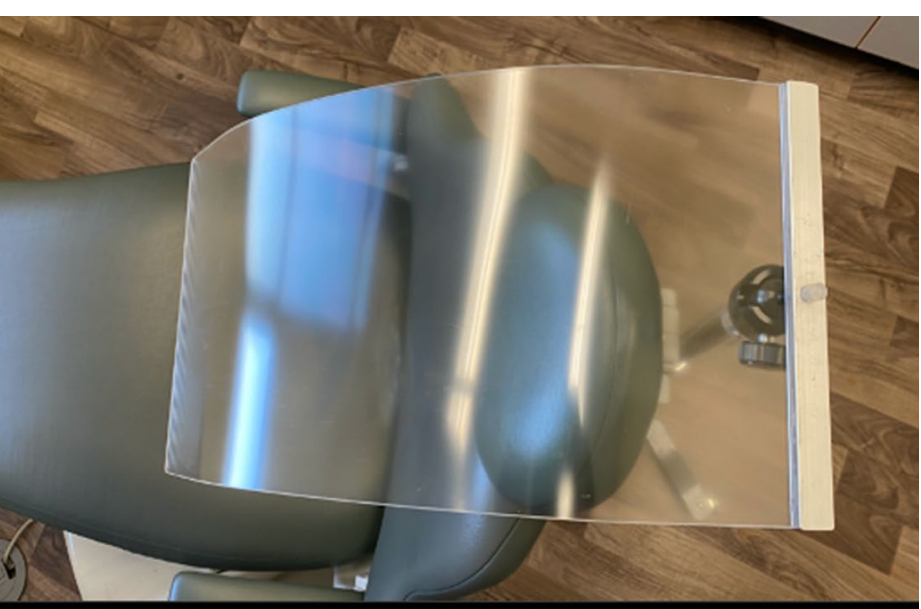

With The Cupola

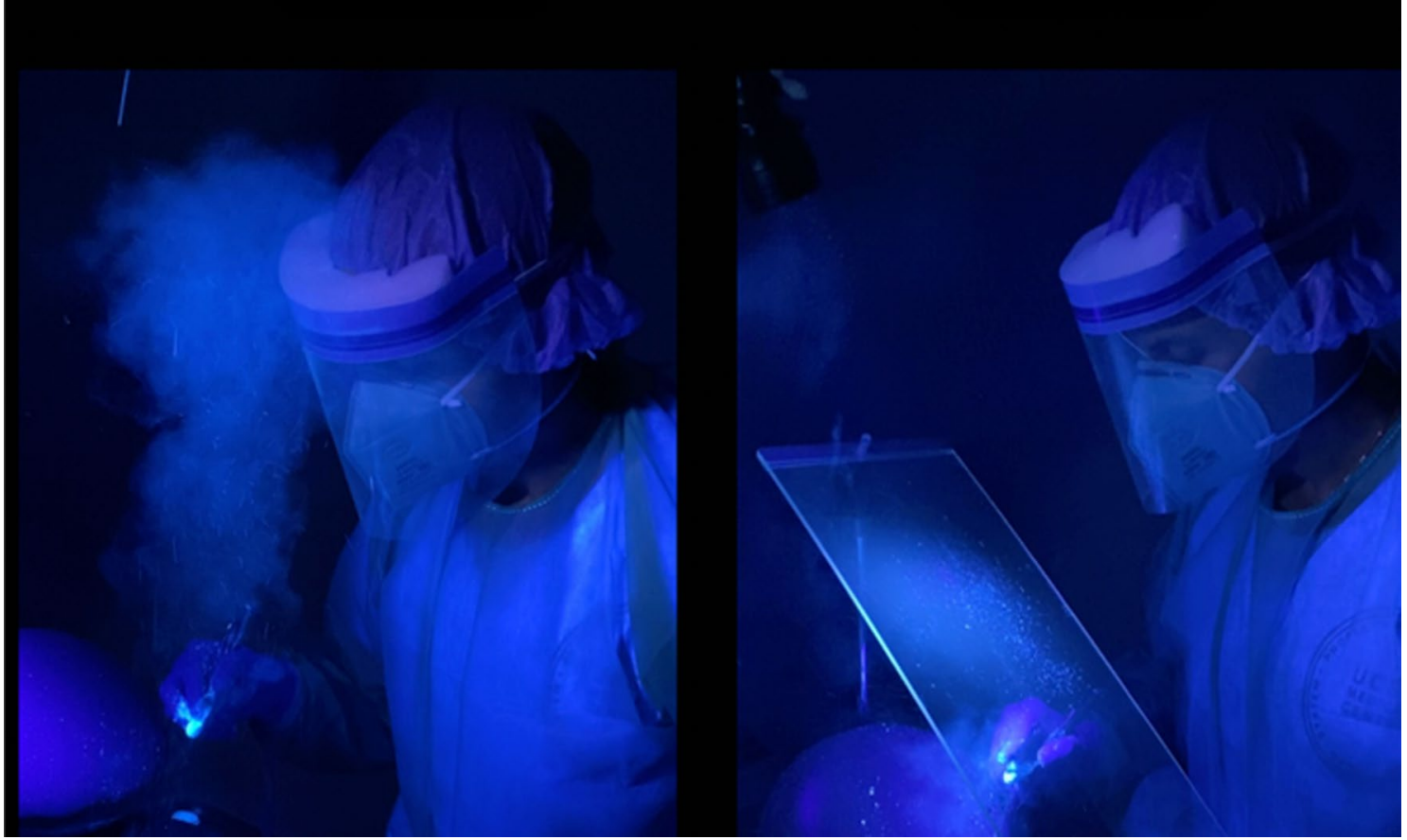

Fig. 1 a The Cupola_protective shield. b Simulated dental procedure using a high-speed handpiece without and with The Cupola 


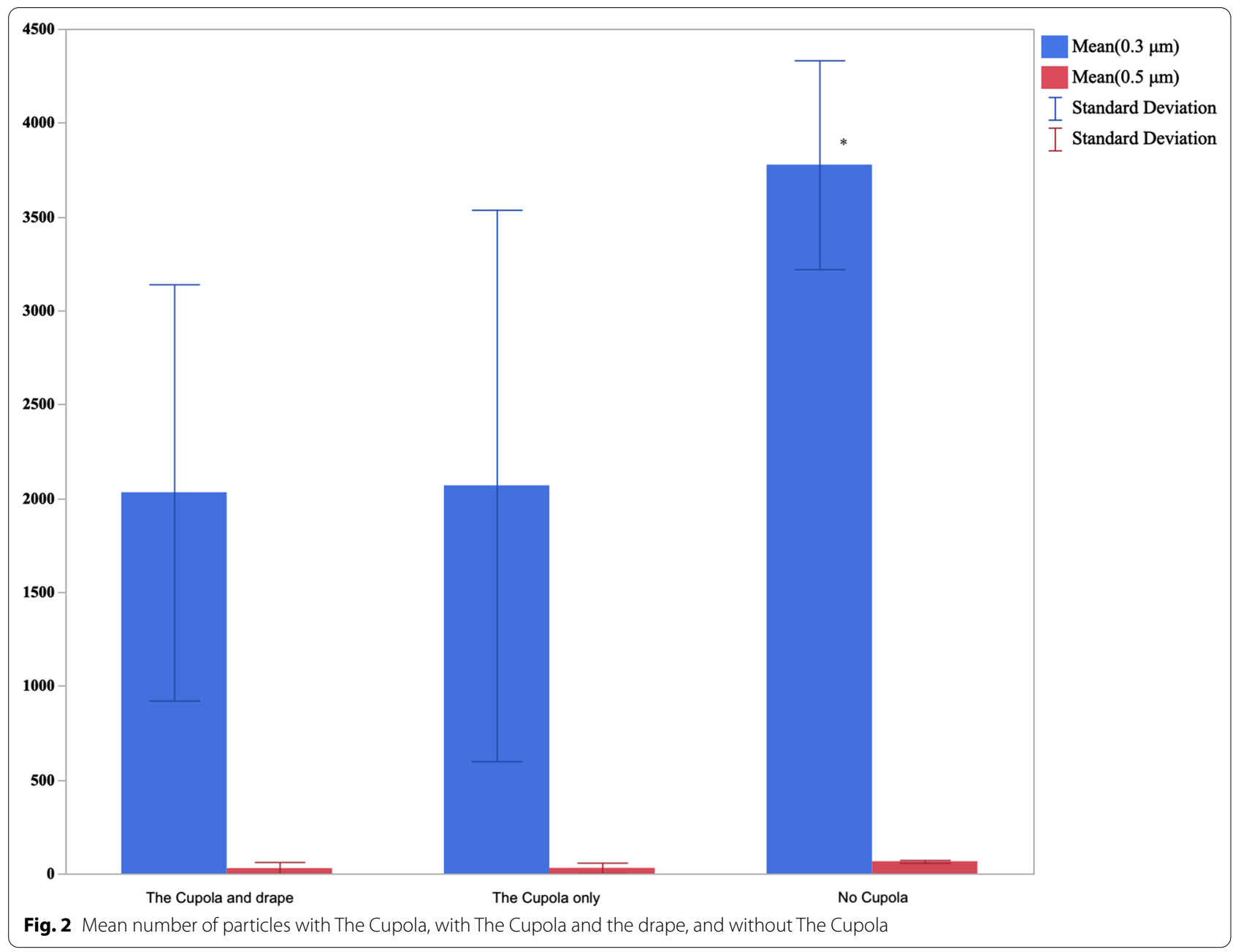

\section{Main text}

\section{Macroscopic contamination}

All experiments were carried out by one of the investigators (A.V.) in a dental office. We used Glo-germ ${ }^{\mathrm{TM}}$ (Glo Germ Company, Moab, UT, USA), a fluorescent resin powder with particle sizes between 1 and $5 \mu \mathrm{m}$ (SARSCOV-2 is $0.07-1.2 \mu \mathrm{m}$ ), with ultraviolet light detection in a darkened dental operatory [11]. Glo-germ ${ }^{\mathrm{TM}}$ was placed into the water lines of the dental chair. Between experiments, the dental chair and surfaces were cleaned with alcohol swipes. All experiments were video recorded using an iPhone 11 (Apple Inc, Cupertino, CA, USA). A simulated dental procedure using a high-speed handpiece was performed without and with The Cupola and repeated for five times. We showed that aerosols generated by the high-speed handpiece were limited when the Cupola was used (Fig. 1b). Specifically, the experiments without The Cupola revealed macroscopic contamination around dental chair and on the face shield of the provider, while during the experiments with The Cupola there was contamination of the inner surface of The Cupola and the provider's gloves.

\section{Microscopic contamination}

We used a high-speed handpiece for $1 \mathrm{~min}$ and repeated the experiment three times without The Cupola, with the Cupola and with The Cupola and drape. Between experiments, the dental chair and surfaces were cleaned with alcohol swipes. The Lighthouse 3016IAQ airborne particle counter (Fremont, CA) was positioned on a tray preset at head height (50 $\mathrm{cm}$ above the dental chair headrest) immediately in front of the provider's head. This height of the airborne particle counter was maintained throughout the duration of the experiment. The airborne particle counter, typically used for indoor air quality testing in semiconductor cleanrooms, research laboratories and operating theatres, utilizes a laser diode and photo detector to count particles by collecting scattered light from particles as they pass through a sample inlet. The 
device counts airborne particles of 0.3, 0.5, 1.0, 2.5 and 5.0 microns. Airborne particle counter flow rate was set to $2.831 \mathrm{~min}^{-1}$ with detection of the ambient air occurring in $1 \mathrm{~s}$ sweeps. All values were normalized against the background particle count present in the room at the start of each recording.

\section{Analyses and results}

We calculated the mean number of airborne particles for all five experiments without The Cupola, with the Cupola and with The Cupola and drape. Differences between the three groups were calculated using the Nonparametric Wilcoxon Test at 1-min intervals [12]. All statistical analyses were carried out using JMP ${ }^{\circledR}$, Version 15; SAS Institute Inc., Cary, NC. Statistical significance was defined as $\mathrm{p}<0.05$.

The mean number of $0.3 \mu \mathrm{m}$ particles with no Cupola was 3777 (SD: \pm 556 ), with The Cupola was 2068 (SD: \pm 1468$)$ and with the Cupola and Drape was 2031 (SD: \pm 1108$)(p<0.015)$. The mean number of $0.5 \mu \mathrm{m}$ airborne particles with no Cupola was 65 (SD: \pm 7 ), with The Cupola was 29 (SD: \pm 28$)$ and with the Cupola and Drape was 28 (SD: \pm 23$)(\mathrm{p}<0.05$; Fig. 2$)$.

\section{Conclusion}

We have shown that The Cupola is effective at decreasing aerosols and droplets generated during simulated dental procedures. With the current pandemic, there is a need for alternate methods to reduce exposure of health care providers to pathogens present in a patient's oral cavity and airways (provider's protection). Even after the COVID-19 pandemic, professionals will continue to be exposed to existing and possible new pathogens. The Cupola provides an additional layer of protection against such pathogens. Several porotypes have been developed over the past few months to include an articulating arm with a clamp for attaching to a headrest or backrest of a dental chair or operating bed. We believe The Cupola will support dental providers and other physicians working in the head and neck area in returning to perform operations with a volume of visits closer to pre-COVID-19 pandemic levels', while keeping staff, patients and themselves safe and allowing opportunities for oral disease management.

\section{Limitations}

One of the limitations of the study was that the aerosol generated procedures were simulated and not on patients. However, the spread of the macroscopic particles may have been even higher because the mouth itself may create a mechanical barrier during dental procedures with high speed instruments. In addition, during most aerosol generating dental procedures with a highspeed hand piece, dentists typically use a rubber dam isolation and/or high-power vacuum suction which may also markedly reduce the spread of virus-contaminated particles.

\section{Acknowledgements}

The author would like to thank Brian Badala for helping during the experiments and Dr. Albert Chin who built the initial prototypes.

\section{Authors' contributions}

AV conducted all the experiments and wrote the manuscript. MG provided critical feedback. Both authors read and approved the final manuscript.

\section{Funding}

None.

Availability of data and materials

Not applicable.

\section{Declarations}

Ethics approval and consent to participate

Not needed.

\section{Consent for publication}

Not applicable.

\section{Competing interests}

The Cupola is patented through the University of California San Francisco. Dr. Villa is the inventor.

\section{Author details}

${ }^{1}$ Department of Orofacial Sciences, University of California San Francisco, 513 Parnassus Ave, Suite 512A, San Francisco, CA 94143, USA. ${ }^{2}$ Innovation Ventures, University of California San Francisco. San Francisco, San Francisco, CA, USA. ${ }^{3}$ Department of Surgery, University of California San Francisco, San Francisco, CA, USA.

Received: 12 January 2021 Accepted: 12 March 2021

Published online: 25 March 2021

\section{References}

1. Peng X, Xu X, Li Y, Cheng L, Zhou X, Ren B. Transmission routes of 2019nCoV and controls in dental practice. Int J Oral Sci. 2020;12(1):9.

2. Widely Used Surgical Masks Are Putting Health Care Workers At Serious Risk. https://khn.org/news/widely-used-surgical-masks-are-puttinghealth-care-workers-at-serious-risk/

3. World Health Organization. Modes of transmission of virus causing COVID-19: Implications for IPC precaution recommendations. Geneva; 2020. https://apps.who.int/iris/bitstream/handle/10665/331601/WHO2019-nCoV-Sci_Brief-Transmission_modes-2020.1-eng.pdf. Accessed 10 Apr 2020

4. WHO Coronavirus (COVID-19) Dashboard. https://covid19.who.int. Accessed 8 March 2021

5. Mick P, Murphy R. Aerosol-generating otolaryngology procedures and the need for enhanced PPE during the COVID-19 pandemic: a literature review. J Otolaryngol Head Neck Surg. 2020;49(1):29.

6. Brian Z, Weintraub JA. Oral Health and COVID-19: increasing the need for prevention and access. Prev Chronic Dis. 2020;17:E82.

7. The American Dental Association. COVID-19: Economic impact on dental practices. https://surveys.ada.org/reports/RC/public/YWRhc3VydmV5cy0 1ZjdiNWU2MDg50TE1YjAwMGViN2JiYWYtVVJfNWIJWDFFU01IdmNDUI VO. Accessed 23 Oct 2020. 
8. DentaQuest Partnership for Oral Health Advancement. Teledentistry: Providing access to care during the COVID-19 crisis. Boston: DentaQuest; 2020.

9. Lutfiyya MN, Gross AJ, Soffe B, Lipsky MS. Dental care utilization: examining the associations between health services deficits and not having a dental visit in past 12 months. BMC Public Health. 2019;19(1):265.

10. United States Patent and Trademark Office. Application number $63 / 048,983$

11. Canelli R, Connor CW, Gonzalez M, Nozari A, Ortega R. Barrier enclosure during endotracheal intubation. N Engl J Med. 2020;382(20):1957-8.
12. Sjaus A, d'Entremont M. Measurement of airborne particle exposure during simulated tracheal intubation using various proposed aerosol containment devices during the COVID-19 pandemic. Anaesthesia. 2020;5:68.

\section{Publisher's Note}

Springer Nature remains neutral with regard to jurisdictional claims in published maps and institutional affiliations.
Ready to submit your research? Choose BMC and benefit from:

- fast, convenient online submission

- thorough peer review by experienced researchers in your field

- rapid publication on acceptance

- support for research data, including large and complex data types

- gold Open Access which fosters wider collaboration and increased citations

- maximum visibility for your research: over $100 \mathrm{M}$ website views per year

At BMC, research is always in progress.

Learn more biomedcentral.com/submissions 